\title{
Factors That Promote/Inhibit Teaching Gifted Students in a Regular Class: Results from a Professional Development Program for Chemistry Teachers
}

\author{
Naama Benny and Ron Blonder \\ Weizmann Institute of Science, 76100 Rehovot, Israel \\ Correspondence should be addressed to Ron Blonder; ron.blonder@weizmann.ac.il
}

Received 13 August 2015; Revised 12 November 2015; Accepted 30 November 2015

Academic Editor: Pablo Gil

Copyright (C) 2016 N. Benny and R. Blonder. This is an open access article distributed under the Creative Commons Attribution License, which permits unrestricted use, distribution, and reproduction in any medium, provided the original work is properly cited.

\begin{abstract}
The current study aims at better understanding the factors that promote and hinder chemistry teachers in teaching a gifted student in their regular chemistry class. In addition, it provides evidence of ways that teachers perceive a professional development course dealing with a gifted student in a mixed-abilities science classroom. Eighty-four photonarratives were collected from 14 chemistry teachers that participated in the course about teaching a gifted student in a regular classroom ( 41 promoting, 43 hindering factors). Factors that concern chemistry education specifically as well as general practices were raised by the teachers. The teachers were asked to "take a picture" (namely, of an external object or person); they considered most of the factors to be internal factors that are dependent on themselves and therefore concluded that they have the power to influence them. The internal factors can be addressed in the PD course; however the external factors should be managed by the school principal and district educational administration.
\end{abstract}

\section{Introduction}

Gifted students should continually utilize their high abilities in order to keep developing their academic skills and their eminent thinking abilities. They should establish their basic cognitive ability in order to prepare themselves for future challenges [1]. Gifted students should have access to learning opportunities that are faster paced and more complex than what is usually available in a regular classroom with students having mixed abilities [2], but this is not trivial to establish. However, if during their school years, gifted students are not provided with a suitable education, they may lack the experience needed to utilize their high abilities [3]. In order to understand the need for giving a special attention to teaching the gifted student in a regular classroom it is important to know that in Israel most of the gifted students study the scientific classes (e.g., chemistry, physics, and science) in regular classrooms. It is therefore common to find one or two gifted students in each class $[4,5]$. However, the teachers do not receive any special training how to address the need of the gifted student in their regular classroom. The current paper describes the PD that was designed to address this need and elaborates on the support that was given to the teachers (regarding teaching a gifted student in a regular chemistry classroom).

Intellectual gifted students have a natural inner interest in natural sciences. They seek to discover and better understand the "rules" behind natural phenomena and how to apply them [6-9]. Science, in general, and chemistry, in particular, generate many questions worth exploring that relate to the matter that composes everything around us [9]. Although content is important for all students, it becomes critical for teachers working with gifted students in the science classroom. Gifted students are more advanced regarding scientific content and need educators who possess an advanced understanding of the subject to accelerate these students beyond the typical curriculum content areas, with emphasis on learning and understanding concepts rather than memorizing facts [10]. Chemistry is a dynamic area that influences life and can be explored by scientific inquiry. It has abstract explanations to observable phenomena [11] and a system of rules (e.g., the periodic table) that can be used to explain patterns of 
the properties of matter; however, there are many exceptions. All these characterizations make chemistry a perfect area that can challenge gifted students in the chemistry classroom. The person who can promote or inhibit this challenging opportunity is the chemistry teacher, who should be supported to be able to help gifted students.

Two trends in researching teachers' behavior in class were pointed out. The first emphasizes the teacher's personality and attitudes. The other trend emphasizes the cognitive dimensions of teachers' behavior. There is a consensus regarding the importance of both trends [12]. Examining teachers' effectiveness (effective teacher as a concept is the sum of multiple teacher's factors: high expectations for all students and helping them learn; contributing to positive academic, attitudinal, and social outcomes for students; using diverse resources to plan and structure engaging learning opportunities; monitoring student progress formatively, adapting instruction as needed; evaluating learning using multiple sources of evidence; and collaborating with others to ensure students' success [13]) when they function within the classroom revealed that they can be effective with one group of students but may not be effective with others [14]. With respect to gifted students, much is known about effective instructional practice and therefore teaching strategies that are widely perceived to be effective should be implemented. Sisk [15] describes models and strategies that can be used by the teacher to provide the gifted student with suitable learning opportunities. However, effective teaching involves more than just using a good strategy [16]. Westberg et al.s [17] research on teachers indicated that only a small degree of differentiation in the instructional and curricular practices, including the grouping arrangements and verbal interactions, has generally been provided for gifted students in regular classrooms. Passow [18] defined differentiated instruction as a process of individualizing curricula to better match individual and group learning needs, abilities, and styles. Sets of specialized learning experiences embody differing learning rates, styles, interests, and abilities [18]. Differentiation is constructed of four curriculum-related elements: content, process, product, and affect, which are based on three categories of student need and variance-readiness, interest, and learning profile [19]. Curriculum compacting [20] is an example of differentiating content method for gifted students. Curricular compacting involves (1) defining the goals and outcomes of a particular unit or segment of instruction, (2) determining and documenting which students have already mastered most or all of a specified set of learning outcomes, and (3) providing replacement strategies for material already mastered through the use of instructional options that enable a more challenging and productive use of the student's time [21]. The VanTasselBaska's integrated curriculum model provides another model for differentiation [22]. It has three dimensions: (a) advanced content, emphasizing advanced content knowledge that frames disciplines of study, (b) high-level process and product work, and (c) organizing learning experiences around major issues, themes, and ideas that define understanding of a discipline and provide connections across disciplines [22].
Across five subject areas and over a period of 92 days of observation, gifted students received instruction in homogeneous groups only $21 \%$ of the time [23]. A recent study examined teachers' interactions with a gifted student in a regular science classroom. (This study will be soon published in Benny, N., Blonder, R. (in press). "Excuse me teacher, but you made a mistake..." Interactions between science teachers and gifted students in a regular classroom. In M. Sumida and K. S. Taber (Eds.), Science education for gifted. Routledge.) This study showed that teachers' knowledge regarding gifted students and their awareness of the available teaching strategies for the gifted population are important factors influencing teachers' interactions with gifted students and that they promote student learning and development in class. Most of the preservice teachers training programs do not adequately prepare teachers to meet the needs of gifted students $[24,25]$, and therefore most of the teachers lack the knowledge to foster learning of the gifted student in a regular class. In some cases with untrained teachers, it is possible they will ignore gifted students and will avoid interactions with them because they are a small minority in the classroom [16]. In order to create a change there is a need to influence the knowledge and the attitudes of in service teachers.

However, it is not easy for teachers to make changes in the way they teach [26]. Guidance and support as well as knowledge can be given through continuous professional development (CPD) programs $[27,28]$. CPD programs that provide teachers with knowledge and support its implementation in their teaching have been proven to create sustainable change in the way teachers teach [29] and the way they consider learning style of different students in their class [30]. Different factors influence the quality of teacher PD programs, such as the fit to teachers' expectations and beliefs, and their classroom situation (e.g., [31, 32]) as well as the extent to which the CPD meets teachers' needs [33]. In view of teacher professional development programs, [34] described three levels of effects. Based on different studies reported in the literature, Lipowsky [34] emphasizes that effects on students' level can only be reached if the classroom setting and teaching are improved. To achieve this by CPD programs, teachers must be convinced and motivated to apply the presented content to school practice. Therefore, the teachers' knowledge gain and a development or even change of their beliefs about successful teaching and learning must be approached in a first step. Studies on teacher training programs indicate that short-term programs might have no long-lasting effect [35] whereas longer programs might have an effect because they allow for ambitious learning activities [36]. There is growing evidence that professional development programs for teachers focusing on teaching gifted students have proved to be effective [25, 37-39]. Teachers who participated in such programs tended to be more supportive for the gifted in their class. However, the goal of the course presented in the current paper is to achieve more than supportiveness of the teachers. Chemistry teachers in a mixed-ability class need to employ appropriate methods of instruction that will address all their students' diverse abilities to understand the subject and still be interesting and challenging to the gifted students in the chemistry 
classroom. The presence of a gifted student in class challenges the teachers' regular practice (e.g., the teaching strategies that they implement in class, the skills that the teacher fosters, the teacher's grouping of students to assignments, the examples the teacher provides, the kind of assignments being used, and the amount of work the teacher demands in order to master a topic) $[2,10,40,41]$. Another challenge for chemistry teachers is to design the learning environment in a way that gifted students can fully develop their abilities and interests without losing their sense of membership as part of the class. Understanding why chemistry teachers do not provide enough educational provision for the gifted student in their regular classroom, one needs to recognize the barriers that inhibit teachers in this aspect. Four major inhibitors for teachers' instruction with gifted students in a regular classroom were described by VanTassel-Baska and Stambaugh [25]. The first major potential inhibitor to appropriate modification of the curriculum for gifted students in the mixed-ability class is content knowledge. Gifted students learn faster and many times are more advanced regarding scientific content matter. Therefore, they need teachers that possess an advanced knowledge and understanding of the subject [10]. When teacher's content knowledge does not match the need of the gifted students, inhibition of the educational provision of the gifted student is expected. The second potential inhibitor is lack of knowledge about differentiating instruction and appropriate modification of the curriculum for gifted students. Many educators feel that they are outside their comfort zone when they are asked to adopt the curriculum to make it sufficiently challenging for gifted students and perceive it as highly time consuming task (e.g., to plan more than one lesson plan simultaneously and to think up advanced and diverse learning activities [25, 42]). The third potential inhibitor is lack of relevant pedagogical and classroom management skills. Classroom practices that address learner differences can include accelerated learning, curriculum compacting [20]; enrichment; providing learning centers; independent study; interdisciplinary curricula; problem-based curricula; and instructional style preferences $[2,10,21,43]$. Addressing learner differences requires knowing when a particular approach will be most effective and how to meaningfully implement that approach for a gifted student [16]. Diverse practices often require mobility in the classroom [25], providing more freedom for and sharing power with students, as well as encouraging decision making and ownership surrounding learning [44]. Teachers attitudes towards the gifted student in a regular class are the center of VanTassel-Baska and Stambaugh [25] inhibitors. Research on teachers' attitudes toward gifted students presents a mixed picture. Some studies suggested that teachers tend to have positive attitudes toward gifted students (e.g., [45]), whereas other studies found that teachers tend to hold more negative attitudes toward gifted students in their class (e.g., [46]); some reported both positive and negative attitudes (e.g., $[47,48]$ ). When teachers' attitudes are negative they become a potential inhibitor [25].

Teachers' beliefs about particular students and classrooms become critical components in their choice of using specific methods of instruction [49]. Constructing beliefs about students enables teachers to approach their teaching tasks professionally, interact with students, and design appropriate instruction for them [50].

The existing PD courses for teaching the gifted student in a regular classroom were focused on the general aspects of teaching gifted students [51-54]. No specific course was reported that gave attention to teaching the gifted in the chemistry classroom in the regular classroom. In order to provide teachers with an appropriate program, their perspectives should be clarified regarding the hindering and promoting factors related to teaching gifted students in a regular chemistry class and these perspectives should be addressed and monitored in the course. We therefore designed a PD course that continues (14 meetings) and took place during the school year to provide teachers with the opportunity to implement and try out in their classes what they learn in the course, as will be described later. The PD course included components that we intended to address teachers' inhibitors and to provide them with the knowledge that is needed to promote a gifted student in their regular chemistry class, as will be described next.

\section{The Context of the Study: Professional Development Course}

The objectives of the PD course "best practices for gifted students" were to become acquainted with and to get a better understanding of the field of gifted and talented student education, and to learn models and strategies that can support them teaching a gifted student in a regular class. Based on the literature of teachers' PD the course consisted of 14 meetings of two hours (during one school year) and provided the teachers with an opportunity to implement what they learn in their class during the course. The PD presented an overview of the concepts and the main characteristics of gifted students and provided the teachers with an opportunity to reflect on their own beliefs regarding gifted students [55]. In the course, the research literature regarding gifted students was examined and the relationship between the literature and the best practices that are useful for science classroom use was discussed. The course included the following topics:

(1) Characteristics and needs of gifted students.

(2) Addressing the social and emotional needs of gifted students in the classroom.

(3) Science education for gifted students.

(4) Modified instruction and strategies for best practices.

(5) Developing creative thinking and creativity.

(6) Technological tools and platforms for teaching the gifted student in a regular classroom.

(7) Hindering and promoting factors for teaching a gifted student in a regular science classroom.

Each week the students participated in a class meeting and read a given article, a book chapter or watched a movie and focused on one of the class topics. After each topic the teachers were given an assignment in which they were 
asked to implement what they learn in their teaching in different ways. For example, after learning the first topic of characteristics and needs of gifted students the teachers were asked to identify a gifted student (or more than one) in their class and to write his (or her) characterizations, and in the next meeting the teachers discussed their findings in the group and found differences between the ways each perceived the definition of giftedness. Another example, after learning about modified instruction and strategies for best practices they were asked to read the paper of VanTasselBaska [2] that presents six different teaching strategies that can be used to foster learning of gifted students. The teachers were asked to prepare a teaching sequence of one of the curricular topics according to this approach and to include at least 2 of the strategies that were suggested in the paper. In the next meeting the teachers presented their teaching sequence and the group discussed the potential effectiveness of the suggested strategy in the specific curricular topic for the gifted student, and difficulties they faced to complete the assignment. Two of the authors served as instructors for the course: the first author is a senior researcher in science education, and the second author is a doctoral student in science education, who has served for 15 years as the principal of a special school for gifted students.

2.1. The Photonarrative Assignment. In order to support teachers' implementation of the course content in their science teaching (related to the gifted student in their regular classroom), we introduced the photonarrative assignment that shed light on factors that inhibit and factors that support teachers to teach the gifted students in their regular science classroom.

Towards the end of the course, the participants heard a lecture about two studies: (1) Goldston and Nichols [56] study and (2) Madden et al. [57] study. The papers describe teachers' creation of photonarratives to reflect on their practices and their forming of a community of science educators. The participants then responded to the following prompt:

For this assignment, you will create a photonarrative specific to your own teaching and school environment, keeping in mind that our focus is gifted students in a regular class. You should take 6 digital photographs around your school and community: three that depict factors that help you promote the learning of a gifted student in your science class and three that hinder it. With each photograph, include a 0.5-1-page description of its significance, referring to other topics discussed in our course. Include a $0.5-$ 1-page introduction and conclusion to provide context and connections between your six photographs, and their perspectives regarding the photonarratives assignment.

Each participant created a photonarrative and submitted it to the two course instructors, who provided written feedback using a rubric. Rubric categories included the style, the connection between photographs and the course content, and the richness of the rationale for each photograph chosen. Next, each participant selected four photographs from their photonarrative (two helping and two hindering factors most representative of their teaching) to share with the class during a class presentation. This act of sharing their individual teaching context was done in order to discuss the photonarratives among the teachers and to find together with the teachers common factors that influence their teaching of the gifted student in their regular classroom.

The photonarrative assignment was chosen for two reasons: (I) During the course the teachers read VanTasselBaska's article [2] regarding selecting instructional strategies for gifted learners. The strategies in the paper include bibliotherapy. Phototherapy (using photonarratives) is a complementary strategy to bibliotherapy and therefore it represents a teaching strategy that is relevant for the course. (II) Photonarratives are a strategy that was reported as a means to "reveal the ways place, time, and space shape relationships, interactions, and events for which teachers perceive themselves" within their school community $[56,58]$.

\section{Objectives and Research Questions}

The current study is intended for learning about chemistry teachers who underwent a professional development program on teaching a gifted student in a regular chemistry class. It is aimed at understanding those factors that promote chemistry teachers, who went through a professional development program, in teaching a gifted student in their regular chemistry class, and those factors that hinder them. In addition, it provides evidence on the usefulness of PD about teaching a gifted student in their class. More specifically, we focused on the following questions:

(1) Which features do teachers consider as helpful or hindering to their teaching of gifted students in their chemistry class when they develop a task-structured photonarrative?

(2) What are teachers' perceptions of the usefulness of a professional development course dealing with the gifted student in a regular chemistry classroom?

\section{Methods}

4.1. Participants. Fourteen teachers enrolled in the professional development (PD) course "Best practices for gifted and talented students." Eleven of the teachers were female; three were male. The PD took place during one school year. Thirteen participants were practicing middle- or high-school teachers in regular schools; one was a teacher in a special school for gifted children. All the teachers taught in science disciplines. The participants teach 15-18-year-old students in mixed-ability chemistry classrooms. Namely, the students' abilities ranged from high ability students to students who straggle with the subject matter. That abilities range is realized in their prior knowledge, learning pace, the amount of practice they need, and so forth. As was mentioned above, in Israel gifted students learn the scientific courses in regular (mixed-ability) classrooms and therefore the PD course was focused on teaching the gifted student in a regular science classroom. The teachers came from different geographical 
areas in the country and taught in schools from different ethnic groups (Arab, Jewish, Religious, and Secular). All of the participants had received a M.S. degree in Science Education and had varying levels of teaching experience, ranging from 2 to more than 20 years. This PD was an obligatory course in the M.S. degree in the second year (last year) of their studies.

4.2. Data Sources. Data sources used in this study included three sources: (1) teachers' photonarratives and their written explanation of the meaning of the photos they included, (2) their presentations of their work during the class presentation and the group discussion, and (3) a written reflective feedback at the end of the course.

The participants were given grading criteria for the photonarrative assignment in advance; one of these criteria was to make connections between their photonarratives and the content conveyed in our course. Those connections that were made by the teachers with the reflective feedback at the end of the course provided evidence regarding the effectiveness of the professional development course. A grounded approach was used to identify the main aspects of the teachers' views regarding the factors that promote and factors that inhibit their teaching of the gifted student in the class, which will be described next.

4.3. Data Analysis. Analysis of the photonarratives was based on a constructivist/interpretive qualitative framework [59]. In this approach, the data are collected prior to analysis and are based upon foreshadowed questions. In our study, the images in the photonarratives were first divided into two categories based on the question asked by the teachers in the study: What do you consider as helping and hindering factors when you teach the gifted students in your regular class?

Then, the teachers discussed the different photonarratives in the oral presentation meeting and were asked to write which of the presented photonarratives were identical and which differed from their own photonarratives. Namely, the primary coding scheme of the photonarratives was done by the teachers themselves during the group discussion that followed the photonarrative presentation. This categorization was followed by one researcher choosing independently identified themes in all the photonarratives in order to better understand any potential patterns. The teachers' written text that supported their images was examined and was used to explain and clarify the pictorial data in the images. To ensure that the categories used to understand the photonarratives were meaningful and valid, a second researcher coded the photonarratives using the codes developed and refined by the first author. The researchers discussed the three photonarratives that were differentially categorized until they reached a consensus.

The teachers' views regarding the effectiveness of the different components of the professional development course were deduced from the analysis of their reflections [60]. In addition, we search for the different components of the course in their assignments where they were asked to connect each photonarrative to the PD content and in the written feedback they wrote at the end of the course.

\section{Results and Discussion}

In this section we will present the results and discussion according to research questions.

\subsection{Features That Teachers Consider as Helpful or Hindering} to Their Teaching of Gifted Students in Their Chemistry Class. The participants listed a total of 41 helping and 43 hindering factors in their written photonarratives, and several key themes emerged among the images. Figure 1 displays the codes and results from our analyses of helping (Figure 1(a)) and hindering (Figure 1(b)) factors. The coding of the different factors (presented in Figure 1) was conducted during the discussion section in the course. The participating teachers presented their photonarratives to the group and were asked to find similarities and differences between them. In the research we used their own coding to rank the photonarratives. First we will explain the different factors that were suggested by the teachers as promoting factors and then we will present the inhibitors for teaching a gifted student in a regular classroom.

5.1.1. Factors That Promote Teaching a Gifted Student in a Regular Classroom. Twelve different helping factors emerged in the coding system (Figure 1(a)). The most frequent factor was the inquiry chemistry laboratory. Teachers believe that in the inquiry laboratory setting they can provide a suitable education provision for the gifted students in their class. This factor concerns chemistry education specifically. The teachers described the inquiry chemistry laboratory, which provides an opportunity to develop the gifted student's scientific thinking and creativity [61]. Teachers' perspectives are in alignment with the way researchers perceive chemistry to be a subject with high potential to challenge gifted students [9]. However, the safety instructions in school hinder them from fulfilling their ability to support the gifted students in their class when these students ask a unique question that requires materials that are not in the original plan, as mentioned in the factors "safety" and "materials and supply" that were raised in the inhibiting factors.

An interesting photonarrative of a promoting factor that emerged from the analysis is "teachers' interactions with the gifted," which was raised by 7 teachers. The teachers described their interactions with the gifted students as a personal promoter to support their learning:

\section{The light in her eyes when I answer her questions provided me with a lot of energy. She loves chemistry and understands chemistry; this is my real payment.}

They explained that interacting with the gifted student that has a deep understanding and shows curiosity increases their motivation (teacher's motivation) to support the gifted student's learning. They also indicate that when they create 


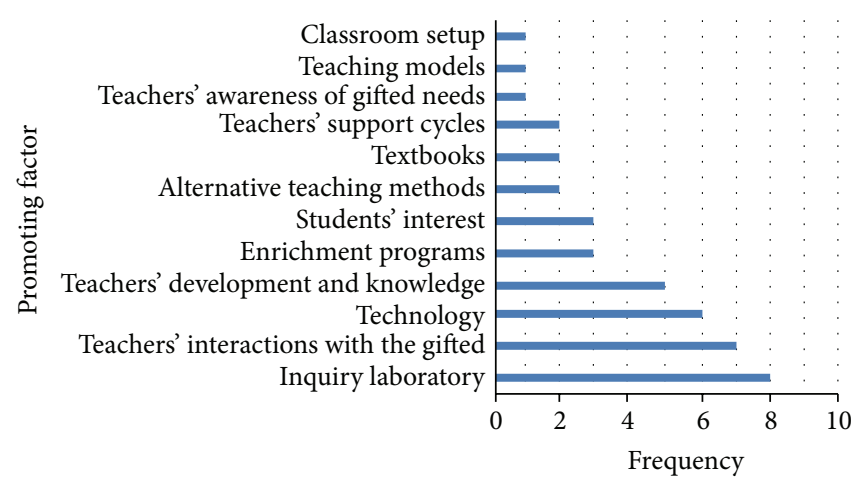

(a)

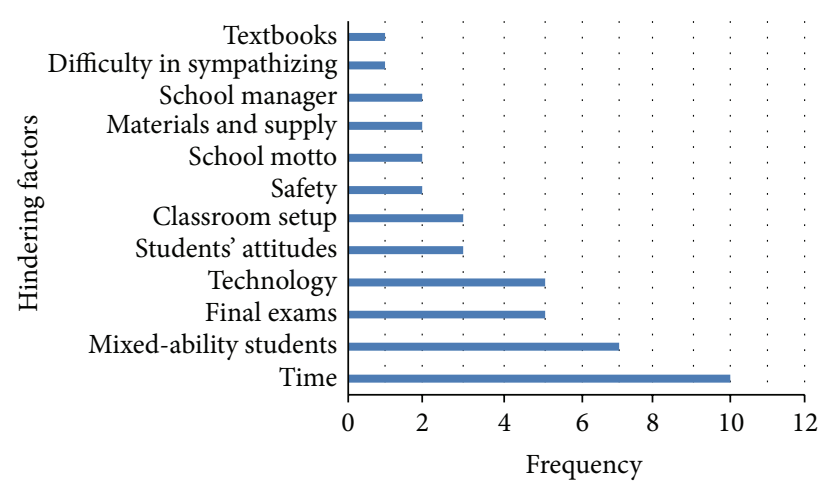

(b)

FIGURE 1: Frequency of helping (a) and hindering (b) factors listed in teachers' photonarratives.

interactions with the gifted student they feel that they promote the student. The two directional interactions indicate a reciprocal influence of the interaction.

Different technology applications and platforms were suggested by the teachers as promoting factors and were all categorized in "technology." For example, the use of QR codons to give a different assignment to a gifted student in the class was suggested as a convincing tool for differentiation.

The photonarrative "teachers' development and knowledge factor" was raised by 5 teachers and reflected their perception that they can influence their ability to promote the gifted student by learning and participating in professional development courses, as they actually do. This photonarrative provides positive feedback to the course, which will be discussed in the next section of the results. Even the factor "technology," which seems to represent an external locus of control, was considered by some of the teachers as an internal factor. They described how they themselves use the computer and the Internet to promote the gifted.

The promoting factor "teachers' awareness of gifted needs" also reflected the teachers' beliefs that their own awareness will promote their educational provision of the gifted student in their class. Using "alternative teaching methods" (e.g., [20]) and using "different teaching models" (e.g., [22]) were additional promoting factors that were suggested by the teachers. In these factors the control of the influence is under the influence of the teacher. However some of the teachers were not fully confident in their ability to implement what they learnt in the course and suggest the promoting factor of "teacher's support cycle" represented experts in the field of teaching the gifted student in a regular class that can support them during implementation stage.

However, the teachers also suggested external factors that can support them. The most typical external factor was the consuming of "enrichment programs." Enrichment programs include the Chemistry Olympics or university courses in chemistry that are open for excellent high-school students. These programs can provide the gifted student with the intellectual challenges that they need. The teachers just need to be aware of such programs and to encourage the student to participate.
Some of the factors were considered by the teachers to be helping as well as hindering factors (e.g., textbooks, technology). Textbooks will inhibit teaching a gifted student when they contain scientific inaccuracies. However, they can promote their learning because they include enrichment activities. Regarding technology, teachers described their use of simulations, videos, and applets in order to demonstrate abstract chemistry concepts and processes [62]. However, the lack of access to working, up-to-date technology is a great hindering factor.

Classroom setup was also suggested as a promoting factor as well as an inhibitor factor. Three teachers reported that the neglected classroom can disrupt the lesson (e.g., broken chairs, wall graffiti) and their attention. Physical environment of the classroom can also help to improve the learning environment and to prevent behavior problems before they occur. It can affect the behavior of both students and teachers [63]. A well-structured classroom tends to improve student academic and behavioral outcomes. In addition, the classroom environment acts as a symbol to students and others and represents teachers' value in behavior and learning [63] and the school administration attitude towards chemistry instruction in school. The teacher who reported the classroom setup narrative as a promoting factor addressed the symbol aspect. In her school, a small and under-budget school, there was no proper laboratory, but the school administration supports and promotes chemistry learning in that school. So, the teacher recognized the school environment and the classroom setup as a supporting factor.

\subsubsection{Inhibitors for Teaching a Gifted Student in a Regu-} lar Chemistry Classroom. Twelve different inhibiting factors emerged in the coding system (Figure 1(b)). The most frequent factor that was raised by the teacher is "time." The teachers showed different pictures they took of watches and clocks and explain that they need more time in order to modify their instruction to meet the needs of the gifted students in their classroom. The next frequent inhibitor was the "mixed-ability classroom." Teachers explained that they need to address the needs of all the students in the mixed-ability 
class and they tend to give more attention to those students who show difficulties. This inhibitor led the teachers to the next inhibitor the "final exam." In Israel there is a system of external examinations (called matriculation examination). At the end of the 11th and 12th grades the students take the chemistry matriculation exam and the teachers feel that this is one of the most part of the role is to prepare all their students for these exams. Therefore they feel that they lack the time to give attention to the gifted students who will succeed anyway in the matriculation exams and prefer to give more attention to the weak students who might fail. The factor technology as an inhibitor was described above in the promoting factors. The photonarrative "students' attitudes" reflects teachers' perception of the gifted students as students who feel smarter than the teachers. The three teachers who raised this inhibitor said that if the gifted student feels like this they are not able and even do not want to promote this student's learning.

School "motto" and school management were suggested to inhibit teaching the gifted student in their class when they lead to contradicting messages. A motto like "all students graduate with a full matriculation" that was presented by one of the teachers leads the teachers to put more efforts on promoting the weak students than enriching the gifted student (as was described above). Other inhibiting factors, suggested by the teachers, (shown in Figure 1(b)) were explained in the previous section about the promoting factors.

Although the teachers were asked to figuratively "take a picture" (namely, of an external object or person), they considered most of the factors to be internal factors that are actually dependent on themselves and therefore they have the power to influence them. Some of the emerging factors were clearly internal, where some teachers even took a picture of themselves (e.g., difficulty in sympathizing). One teacher took a picture of herself dressed up like the stigmatic gifted student (Figure 2) and wrote

\section{I have never experienced how it is to understand quickly and to get bored in school. I always needed all the explanations. I have difficulty in sympathizing with the gifted student...The course supported my ability to understand how they feel.}

5.1.3. A Comparison to the Literature Inhibitors for Teaching the Gifted in a Regular Classroom. VanTassel-Baska and Stambaugh [25] described four major inhibitors of teachers' instruction for gifted students in a regular classroom, as was presented in the Introduction of the paper: (a) differentiating instruction and appropriate modification of the curriculum for gifted students in the mixed-ability class, (b) lack of content matter knowledge, (c) lack of relevant pedagogical and classroom management skills, and (d) negative attitudes and beliefs about gifted students [25]. These four inhibitors include most of the inhibitors described by the teachers in the photonarrative assignment.

The first inhibitor, namely, differentiating instruction and appropriate modification of the curriculum for gifted students in a mixed-ability class, was mentioned twice in the photonarratives: first it is mentioned directly in the photonarrative "mixed-ability students" (Figure 1(b)). Seven teachers are now aware of the need to address the variety of their students in a mixed-ability chemistry classroom and to adapt the curriculum to the level of the gifted students as well. The teachers also referred to this inhibitor in the photonarrative called "time." When they describe this narrative they connected the lack of time to prepare differentiation materials for their lessons. This photonarrative was the most frequently mentioned factor by the teachers (as shown in Figure 1(b)). However, the teachers also referred to the aspect of differentiation in the promoting factors. The factor technology was presented by the teacher as a means for differentiation.

The second inhibitor mentioned by VanTassel-Baska and Stambaugh [25] refers to content knowledge. The teachers that participated in the course mentioned this factor in their supporting photonarratives. Five teachers described teachers' knowledge of the content and teachers' pedagogical knowledge as a promoting factor (Figure 1(a)). The third inhibitor, according to VanTassel-Baska and Stambaugh [25], lack of relevant pedagogical and classroom management skills, was mentioned neither as an inhibiting factor nor as a promoting factor. The last inhibitor, negative attitudes and beliefs about gifted students, was mentioned in three different narratives. One teacher described her "difficulty in sympathizing" (Figure 2). This teacher explicitly wrote that the course supported her in better understanding what gifted students feel in a regular chemistry classroom when they are not challenged and are bored most of the time. This inhibitor is also reflected in the photonarrative "students' attitude" that was suggested as inhibitor by three teachers. When the gifted students demonstrate negative attitudes towards the teacher and the topic the interaction with the teacher cannot be constructive. On the other hand seven teachers reported the interactions with the gifted students in the promoting factors.

We examined what the inhibiting factors are that were raised by the teachers and are not described by VanTasselBaska and Stambaugh [25]: technology (when it is not working or not up-to-date), classroom setup, final exams, safety, textbooks (when they are not accurate), school principle, and school motto. All these inhibiting factors were raised by the teachers as external factors, which they find to have no control on. The teachers feel that in order to better address the needs of the gifted student in a regular classroom they need external support from the system. In the teachers' view the effort to provide the gifted with a proper educational provision should be supported by the school system.

\subsection{Teachers' Perceptions of the Usefulness of a Professional Development Course Dealing with a Gifted Student in a Mixed-Abilities Science Classroom. To understand how the different parts of the professional development course were perceived by the teachers as enhancing their understanding of inhibitors and promoters, their connections of the photonar- rative to the course contents as well as their written feedback assignment were examined.}




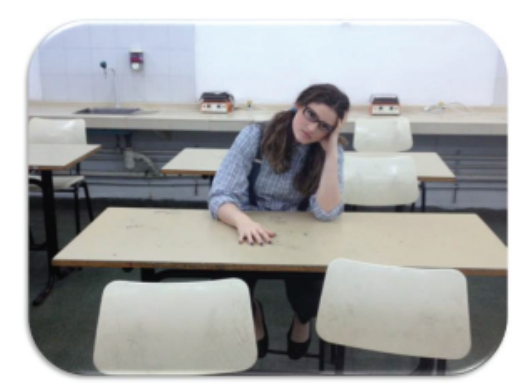

FIGURE 2: A hindering photonarrative "difficulty in sympathizing."

In the feedback the teachers indicated that they now better appreciate the importance of the course. One teacher wrote that

The assignment forced me to think and re-think about the course contents and to truly compare them to what I do with the gifted and to understand why I do them.

The teachers described different aspects in which the course had influenced their perceptions regarding teaching a gifted student in their chemistry class. The first aspect was related to their commitment to teach a gifted student. Several teachers wrote that they now realize that they are responsible for supporting the cognitive development of the gifted students in their class, as reflected from the following:

\section{Before taking this course I thought that they [the gifted students] will manage, they don't need me to succeed. I now understand that I have a lot to give them in my class, although there are other difficulties in my class and I need to deal with them too.}

The teachers' sense of commitment to provide the gifted student with appropriate teaching and teachers' knowledge of the developmental nature of giftedness constitute an essential stage in supporting a gifted student in a regular classroom. In a study in Finland [64], it was shown that when teachers define giftedness they described giftedness as a "thing" that a student is born with; the development aspect is not present in their definitions. The researchers recommend addressing this aspect in teacher education programs.

The next issue for providing appropriate education is teachers' awareness of teaching pedagogies and strategies that can be used in a mixed-ability classroom and providing an intellectual challenge to the gifted students [25]. One of the major parts of the course dealt with modified instruction and strategies for best practices. This part focused on differentiating instruction and appropriate modification of the curriculum for gifted students in a mixed-ability class. The differentiation process requires the creation of multiple lesson plans for every lesson and includes the degree of differentiation required, as well as the need to provide advanced learning opportunities beyond the grade level [25]. Differentiation has unique challenges owing to the unique features of gifted students $[23,42]$, but it also requires a lot of
TABLE 1: Connections between teachers' photonarratives and the PD course's components according to teachers' written reflection.

\begin{tabular}{ll}
\hline Course component & Related photonarratives \\
\hline $\begin{array}{l}\text { (1) Characteristics and } \\
\text { needs of gifted students }\end{array}$ & $\begin{array}{l}\text { Difficulty in sympathizing } \\
\text { Textbooks with enrichment } \\
\text { activities } \\
\text { Enrichment programs }\end{array}$ \\
\hline $\begin{array}{l}\text { (2) Addressing the social } \\
\text { and emotional needs of } \\
\text { gifted students in the } \\
\text { classroom }\end{array}$ & $\begin{array}{l}\text { Teachers' awareness of } \\
\text { gifted students' needs } \\
\text { [Other] students' attitudes }\end{array}$ \\
\hline $\begin{array}{l}\text { (3) Science education for } \\
\text { gifted students }\end{array}$ & $\begin{array}{l}\text { Inquiry laboratory } \\
\text { Students' interest }\end{array}$ \\
$\begin{array}{l}\text { (4) Modified instruction } \\
\text { and strategies for best } \\
\text { practices }\end{array}$ & $\begin{array}{l}\text { Alternative teaching } \\
\text { methods }\end{array}$ \\
\hline $\begin{array}{l}\text { (5) Developing creative } \\
\text { thinking and creativity }\end{array}$ & $\begin{array}{l}\text { Mixed-ability classroom } \\
\text { Time }\end{array}$ \\
\hline $\begin{array}{l}\text { (6) Technological tools and } \\
\text { platforms for teaching the } \\
\text { gifted student in a regular } \\
\text { classroom }\end{array}$ & Inquiry laboratory \\
\hline
\end{tabular}

time invested by the teachers. The time factor was mentioned by several teachers as a hindering factor that inhibits their teaching of gifted students in their chemistry class. Teachers who mentioned the differentiation process that is needed wrote that next year they plan to use the example that they had worked on during the course of preparing a teaching unit that is differentiated as part of the chemistry curriculum. They also asked the course instructors to share the units that were prepared by other teachers in the course.

The technological tools that were presented in the course were described by the teachers as being very effective tools for promoting a gifted student in a regular class. However, as previously noted, and as some of the teachers showed in their photonarrative assignment, the teachers also mentioned their concerns regarding the technical problems in school, which can negate the usefulness of the technological tools.

We found connections between the teachers' photonarratives and the different parts of the course, as described in Table 1 .

All parts of the course are reflected in the teachers' photonarratives, as described in Table 1 . The aspect of developing creative thinking and creativity was only partially included in the description of the inquiry laboratory. The inquiry laboratory is a natural environment for developing creative thinking because students can suggest their own direction for the inquiry [65]. However, two teachers mentioned this opportunity as a hindering factor, which is described in the photonarrative "materials and supplies." They perceived the original inquiry questions of the gifted students as problematic, since the schools usually do not have the materials and the supplies that are needed to deal with these questions. In a previous study that was conducted in a university laboratory where a high-school class was invited to perform advanced chemistry experiments the gifted students 
asked creative inquiry questions [66]. However, this unique university setting had a wide range of materials available and advanced instrumentation that can support students' original inquiry questions.

\subsection{Implication of Teachers' Professional Development Re-} search and Practice. In the current study, chemistry teachers' photonarratives provided the possibility of examining their perceptions regarding inhibiting and promoting factors related to how they teach the gifted students in their classroom. The results provided the researchers with insight into a variety of factors that influence teachers' practices and beliefs regarding gifted students in mixed-ability classrooms. Reinforcing the promoting factors and reducing the hindering factors for teaching gifted students in a regular class may have a positive impact on providing suitable learning opportunities for gifted students as well as for other students in a regular class and enable gifted students to achieve their greatest potential.

In the study we identified inhibiting factors of two kinds: internal inhibiting factors and external factors. The PD course addressed the internal factors and provided the teachers with guides how to overcome these inhibitors and how to empower the promoting factors. In addition, the teachers' discussion in the course in which the teachers shared the way they deal with these inhibitors provided the teachers with a model of their colleagues who managed to overcome the inhibitor. The external inhibitors that were raised by the teachers indicate that teachers PD on its own is not enough for achieving change in gifted education provision. Attention should be given to raise the awareness of school principals, district administration, and their recognition of their responsibility to provide appropriate education services for all students including the gifted student in the regular classroom.

The current study is focused on understanding teachers' inhibitors and promoting factors for teaching the gifted student in a regular chemistry classroom. However gifted students are only one part of the classroom diversity. The mixedability class includes students characterized by different level of cognitive abilities, different motivating and interest, and so forth. The PD course that proved the teachers the understanding and the tool to address the gifted in her class, actually enable the teachers to use the tools that were provided in the course for the benefits of other students' population in the classroom. Using differentiation instruction helps gifted students as well as other students in the class.

Chemistry as a subject matter is a perfect area that can challenge gifted students in the chemistry classroom, as was described in the Introduction. However when we examine the promoting and inhibiting factors that were suggested by the chemistry teachers only three of them were specifically connected to chemistry (laboratory inquiry, safety, and materials and supply). All the other factors are generic and relevant to teaching the gifted student in any regular classroom. We suggest that the results of the current study can be implemented also in other subject matters.

In the PD course we support the teachers to overcome the inhibiting factors and provide them with tools to strengthen the teaching skills that build their promoting factors. One of the promoting factors that was described by half of the teachers was "teachers interactions with the gifted." This aspect has a potential to influence teachers attitudes and willingness to support the development of the gifted student in their mixed-ability class; however not enough research was conducted to study this aspect.

5.4. Research Limitations. The resulting inhibitors and promoting factors that were found in the current paper are the factors that were raised by the science teachers who participated in the PD course that took place in Israel. These factors do not represent all the possible factors. We are aware that other teachers in different context could suggest different inhibitors and other promoting factors for teaching a gifted student in a regular classroom. We suggest further research in additional context in order to obtain a better understanding of the factors that promote and the factors that inhibit science teachers to provide the educational needs of a gifted student in a regular classroom.

\section{Conflict of Interests}

The authors declare that there is no conflict of interests regarding the publication of this paper.

\section{References}

[1] V. H. Burney, "Applications of social cognitive theory to gifted education," Roeper Review, vol. 30, no. 2, pp. 130-139, 2008.

[2] J. Van Tassel-Baska, "Selecting instructional strategies for gifted learners," Focus on Exceptional Children, vol. 36, no. 3, pp. 1-12, 2003.

[3] F. Pajares, "Self-efficacy beliefs in academic settings," Review of Educational Research, vol. 66, no. 4, pp. 543-578, 1996.

[4] B. Eilam and H. E. Vidergor, "Gifted Israeli students' perceptions of teachers' desired characteristics: a case of cultural orientation," Roeper Review, vol. 33, no. 2, pp. 86-96, 2011.

[5] B. Nevo and S. Rachmel, "Education of gifted children: a general roadmap and the case of Israel," in Creativity in Mathematics and the Education of Gifted Students, R. Leikin, A. Berman, and B. Koichu, Eds., pp. 243-251, Sense Publishers, Dordrecht, The Netherlands, 2009.

[6] B. Clark, Growing Up Gifted: Developing the Potential of Children at Home and at School, Prentice-Hall, Upper Saddle River, NJ, USA, 7th edition, 1997.

[7] J. Freeman, "Scientific thinking in gifted children," in Science Education: Talent Recruitment and Public Understanding, vol. 38 of Nato Science Series, pp. 17-30, IOS Press, 2003.

[8] S. K. Johnsen, "Definitions, models, and characteristics of gifted students," in Identifying Gifted Students: A Practical Guide, pp. 1-22, Prufrock Press, Waco, Tex, USA, 2004.

[9] K. S. Taber, Enriching School Science for the Gifted Learner, Gatsby Science Enhancement Programme, London, UK, 2007.

[10] K. S. Taber, "Challenging gifted learners: general principles for science educators; and exemplification in the context of teaching chemistry," Science Education International, vol. 21, no. 1, pp. 5-30, 2010. 
[11] A. H. Johnstone, "The development of chemistry teaching: a changing response to changing demand," Journal of Chemical Education, vol. 70, no. 9, p. 701, 1993.

[12] R. M. Milgram, "Perception of teacher behavior in gifted and nongifted children," Journal of Educational Psychology, vol. 71, no. 1, pp. 125-128, 1979.

[13] L. Goe, C. Bell, and O. Little, Approaches to Evaluating Teacher Effectiveness: A Research Synthesis, National Comprehensive Center for Teacher Quality, 2008.

[14] J. Brophy and T. L. Good, "Teacher behavior and student achievement," in Handbook of Research on Teaching, pp. 238375, Macmillan Publishers, 1986.

[15] D. Sisk, "Myth 13: the regular classroom teacher can 'go it alone," The Gifted Child Quarterly, vol. 53, no. 4, pp. 269-271, 2009.

[16] M. E. Welsh, "Measuring teacher effectiveness in gifted education: some challenges and suggestions," Journal of Advanced Academics, vol. 22, no. 5, pp. 750-770, 2011.

[17] K. L. Westberg, F. X. Archambault Jr., S. M. Dobyns, and T. J. Salvin, "The classroom practices observation study," Journal for the Education of the Gifted, vol. 16, no. 2, pp. 120-146, 1993.

[18] A. H. Passow, "Differentiated curricula for the gifted/talented," in Proceedings of the 1st National Conference on Curricula for the Gifted/Talented, pp. 4-20, National/State Leadership Training Institute on the Gifted and Talented, Ventura, Calif, USA, 1982.

[19] C. A. Tomlinson, Differentiated Classroom: Responding to the Needs of All Learners, ASCD, Alexandria, Va, USA, 2nd edition, 2014.

[20] S. M. Reis and J. S. Renzulli, "Using curriculum compacting to challenge the above-average," Educational Leadership, vol. 50, no. 2, pp. 51-57, 1992, http://www.ascd.org/publications/ educational_leadership/oct92/vol50/num02/Using_Curriculum_ Compacting_To_Challenge_the_Above-Average.aspx.

[21] S. M. Reis and J. S. Renzulli, "Curriculum compacting: a systematic procedure for modifying the curriculum for above average ability students," The Journal of the California Association for the Gifted, vol. 26, no. 2, pp. 27-32, 1995.

[22] J. VanTassel-Baska and S. Wood, "The integrated curriculum model (ICM)," Learning and Individual Differences, vol. 20, no. 4, pp. 345-357, 2010.

[23] K. L. Westberg and M. E. Daoust, "The results of the replication of the classroom practices survey replication in two states," The National Research Center on the Gifted and Talented Newsletter, Fall, 3-8, 2003, http://www.gifted.uconn.edu/nrcgt/ newsletter/fall03/fall032.html.

[24] J. B. Hansen and J. F. Feldhusen, "Comparison of trained and untrained teachers of gifted students," Gifted Child Quarterly, vol. 38, no. 3, pp. 115-121, 1994.

[25] J. VanTassel-Baska and T. Stambaugh, "Challenges and possibilities for serving gifted learners in the regular classroom," Theory Into Practice, vol. 44, no. 3, pp. 211-217, 2005.

[26] B. Joyce and B. Showers, Power and Staff Development through Research on Training, Association for Supervision and Curriculum Development, Alexandria, Va, USA, 1983.

[27] J. Harrison and R. Globman, Assessment of Training Teachers in Active Learning: A Research Report, Bar-Ilan University, Ramat Gan, Israel, 1988 (Hebrew).

[28] S. Loucks-Horsley and C. Matsumoto, "Research on professional development for teachers of mathematics and science: the state of the scene," School Science and Mathematics, vol. 99, pp. 258-271, 1999.
[29] R. Mamlok-Naaman, R. Blonder, and A. Hofstein, "Providing chemistry teachers with opportunities to enhance their knowledge in contemporary scientific areas: a three-stage model," Chemistry Education Research and Practice, vol. 11, no. 4, pp. 241-252, 2010.

[30] R. Blonder and R. Mamlok-Naaman, "Learning about teaching the extracurricular topic of nanotechnology as a vehicle for achieving a sustainable change in science education," International Journal of Science and Mathematics Education, 2015.

[31] L. Darling-Hammond and N. Richardson, "Teacher learning: what matters?" Educational Leadership, vol. 66, no. 5, pp. 4653, 2009.

[32] C. Gräsel, C. Pröbstel, J. Freienberg, and I. Parchmann, "Fostering collaboration among secondary school science teachers," in Studies on the Educational Quality of Schools. The Final Report on the Dfg Priority Programme, M. Prenzel, Ed., pp. 157-173, Waxmann, Münster, Germany, 2007.

[33] J. H. van Driel, A. M. W. Bulte, and N. Verloop, “The conceptions of chemistry teachers about teaching and learning in the context of a curriculum innovation," International Journal of Science Education, vol. 27, no. 3, pp. 303-322, 2005.

[34] F. Lipowsky, "Theoretische perspektiven und empirische befunde zur wirksamkeit von lehrerfort- und -weiterbildung," in Handbuch der Forschung zum Lehrerberuf, E. Terhart, H. Bennewitz, and M. Rothland, Eds., pp. 398-417, Waxmann, Münster, Germany, 2011.

[35] A. J. Wayne, K. S. Yoon, P. Zhu, S. Cronen, and M. S. Garet, "Experimenting with teacher professional development: motives and methods," Educational Researcher, vol. 37, no. 8, pp. 469-479, 2008.

[36] M. S. Garet, A. C. Porter, L. Desimone, B. F. Birman, and K. S. Yoon, "What makes professional development effective? Results from a national sample of teachers," American Educational Research Journal, vol. 38, no. 4, pp. 915-945, 2001.

[37] J. Feldhusen, "Educating teachers for work with talented youth," in Handbook of Gifted Education, N. Colangelo and G. A. Davis, Eds., pp. 547-552, Allyn \& Bacon, Boston, Mass, USA, 2nd edition, 1997.

[38] J. G. Geake and M. U. M. Gross, “Teachers' negative affect toward academically gifted students: an evolutionary psychological study," Gifted Child Quarterly, vol. 52, no. 3, pp. 217-231, 2008.

[39] D. J. Matthews and J. F. Foster, "A dynamic scaffolding model of teacher development: the gifted education consultant as catalyst for change," Gifted Child Quarterly, vol. 49, no. 3, pp. 222-230, 2005.

[40] R. S. Matthews, B. L. Smith, and J. MacGregor, "The evolution of learning communities: a retrospective," New Directions for Teaching and Learning, no. 132, pp. 99-111, 2012.

[41] C. Midgley, A. Kaplan, and M. Middleton, "Performanceapproach goals: good for what, for whom, under what circumstances, and at what cost?" Journal of Educational Psychology, vol. 93, no. 1, pp. 77-86, 2001.

[42] H. Hertberg-Davis, "Myth 7: Differentiation in the regular classroom is equivalent to gifted programs and is sufficient: classroom teachers have the time, the skill, and the will to differentiate adequately," Gifted Child Quarterly, vol. 53, no. 4, pp. 251-253, 2009.

[43] J. VanTassel-Baska, "Effective curriculum and instructional models for talented students," Gifted Child Quarterly, vol. 30, no. 4, pp. 164-169, 1986. 
[44] M. Gentry, M. G. Rizza, and S. V. Owen, "Examining perceptions of challenge and choice in classrooms: the relationship between teachers and their students and comparisons between gifted students and other students," Gifted Child Quarterly, vol. 46, no. 2, pp. 145-155, 2002.

[45] F. Gagne, "Perceptions of programs for gifted children: agreement on principles, but disagreement over modalities," Journal of Special Education, vol. 7, no. 2, pp. 113-127, 1983.

[46] B. Cramond and C. E. Martin, "Inservice and preservice teachers' attitudes toward the academically brilliant," Gifted Child Quarterly, vol. 31, no. 1, pp. 15-19, 1987.

[47] R. W. Copenhaver and D. J. Mc Intyre, “Teachers' perception of gifted students," Roeper Review, vol. 14, no. 3, pp. 151-153, 1992.

[48] K. Megay-Nespoli, "Beliefs and attitudes of Novice teachers regarding instruction of academically talented learners," Roeper Review, vol. 23, no. 3, pp. 178-182, 2001.

[49] R. C. Pianta, B. Hamre, and M. Stuhlman, "Relationships between teachers and children," in Handbook of Psychology, W. M. Reynolds and G. E. Miller, Eds., John Wiley \& Sons, Hoboken, NJ, USA, 2003.

[50] J.-E. Nurmi, "Students' characteristics and teacher-child relationships in instruction: a meta-analysis," Educational Research Review, vol. 7, no. 3, pp. 177-197, 2012.

[51] K. A. Ericsson, "The influence of experience and deliberate practice on the development of superior expert performance," in The Cambridge Handbook of Expertise and Expert Performance, K. A. Ericsson, N. Charness, P. J. Feltovich, and R. R. Hoffman, Eds., pp. 683-703, Cambridge University Press, New York, NY, USA, 2006.

[52] J. S. Renzulli, "Reexamining the role of gifted education and talent development for the 21st century: a four-part theoretical approach," Gifted Child Quarterly, vol. 56, no. 3, pp. 150-159, 2012.

[53] R. J. Sternberg and L. Zhang, "What do we mean by giftedness? A pentagonal implicit theory," Gifted Child Quarterly, vol. 39, no. 2, pp. 88-94, 1995.

[54] R. F. Subotnik, P. Olszewski-Kubilius, and F. C. Worrell, "Rethinking giftedness and gifted education a proposed direction forward based on psychological science," Psychological Science in the Public Interest, vol. 12, no. 1, pp. 3-54, 2011.

[55] J. J. Haney, A. T. Lumpe, C. M. Czerniak, and V. Egan, "From beliefs to actions: the beliefs and actions of teachers implementing change," Journal of Science Teacher Education, vol. 13, no. 3, pp. 171-187, 2002.

[56] M. J. Goldston and S. Nichols, "Visualizing culturally relevant science pedagogy through photonarratives of black middle school teachers," Journal of Science Teacher Education, vol. 20, no. 2, pp. 179-198, 2009.

[57] L. Madden, M. G. Jones, and M. Blanchard, "Shared photonarratives in an online master's course: reflection, context and community," Contemporary Issues in Technology and Teacher Education, vol. 13, no. 1, 2013, http://www.citejournal.org/vol13/iss1/ science/articlel.cfm.

[58] B. Hooks, Art on My Mind, New York Press, New York, NY, USA, 1995.

[59] E. G. Guba and Y. S. Lincoln, "Competing paradigms in qualitative research," in Handbook of Qualitative Research, N. K. Denzin and Y. S. Lincoln, Eds., pp. 105-117, Sage, Thousand Oaks, Calif, USA, 1994.

[60] J. W. Creswell and V. L. Plano Clark, Designing and Conducting Mixed Methods Research, Sage, New York, NY, USA, 2nd edition, 2011.
[61] A. Hofstein, R. Shore, and M. Kipnis, "Providing high school chemistry students with opportunities to develop learning skills in an inquiry-type laboratory: a case study," International Journal of Science Education, vol. 26, no. 1, pp. 47-62, 2004.

[62] R. Blonder, M. Jonatan, Z. Bar-Dov, N. Benny, S. Rap, and S. Sakhnini, "Can you tube it? Providing chemistry teachers with technological tools and enhancing their efficacy beliefs," Chemistry Education Research and Practice, vol. 14, no. 3, pp. 269-285, 2013.

[63] A. F. L. Wong and B. J. Fraser, "Assessment of chemistry laboratory classroom environments," Asia Pacific Journal of Education, vol. 17, no. 2, pp. 41-58, 1997.

[64] S. Laine, E. Kuusisto, and K. A. Tirri, "Finnish teachers' conceptions of giftedness," in Proceedings of the American Educational Research Association AERA 2015 Annual Meeting, Chicago, Ill, USA, April 2015.

[65] R. Blonder, S. Rap, R. Mamlok-Naaman, and A. Hofstein, "Questioning behavior of students in the inquiry chemistry laboratory: differences between sectors and genders in the israeli context," International Journal of Science and Mathematics Education, vol. 13, no. 4, pp. 705-732, 2015.

[66] R. Blonder, R. Mamlok-Naaman, and A. Hofstein, "Analyzing inquiry questions of high-school students in a gas chromatography open-ended laboratory experiment," Chemistry Education Research and Practice, vol. 9, no. 3, pp. 250-258, 2008. 


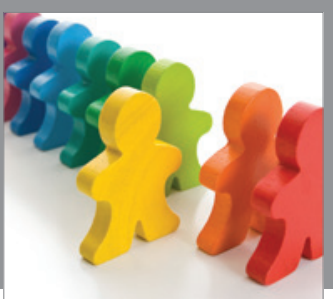

Autism

Research and Treatment
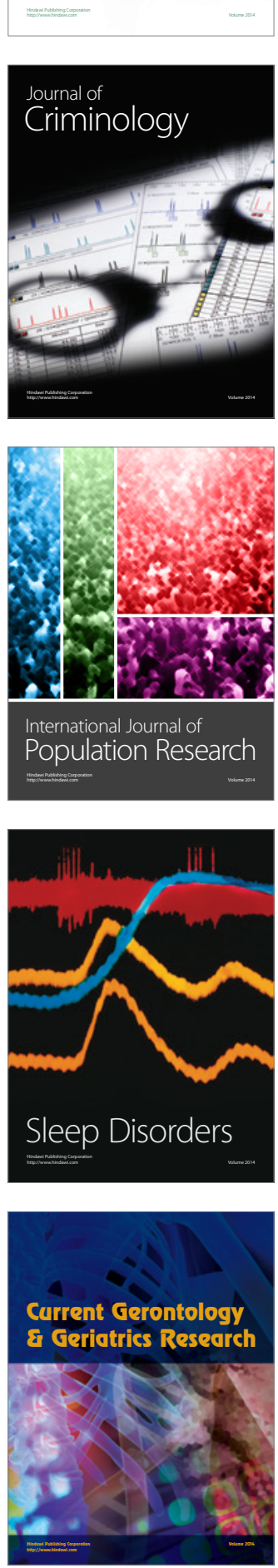

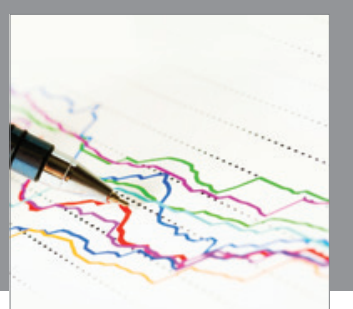

Economics

Research International
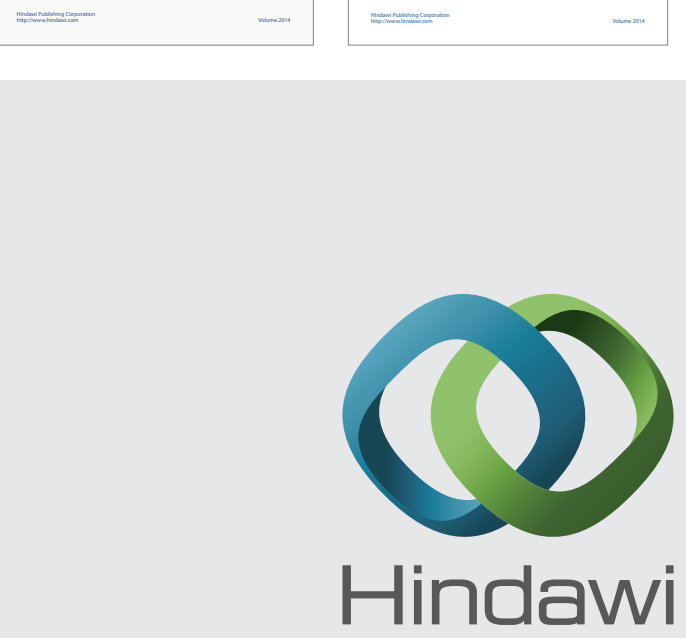

Submit your manuscripts at

http://www.hindawi.com
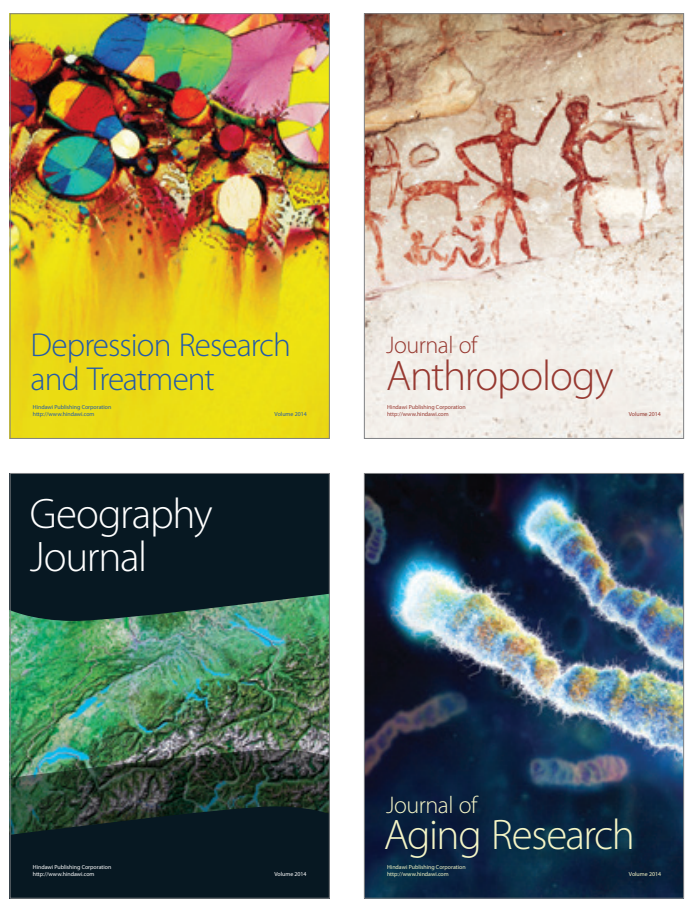
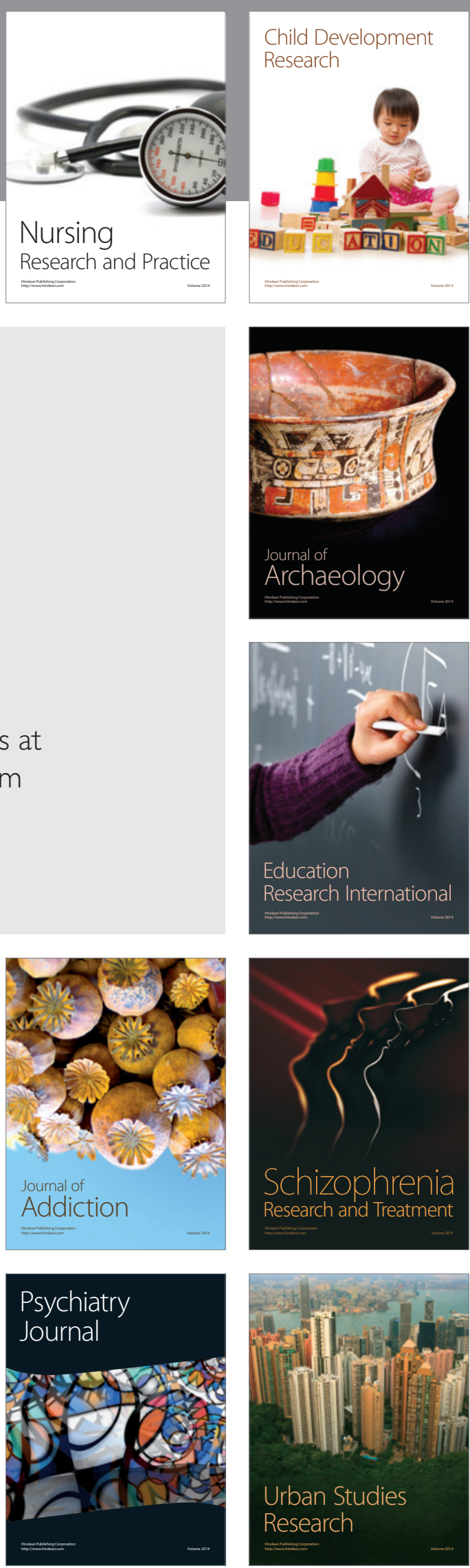